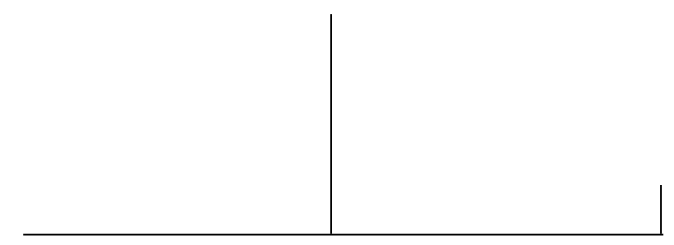

Rev. Latinoam. Psicopat. Fund., São Paulo, v. 13, n. 2, p. 207-223, junho 2010

\title{
The analyst's desire in the clinic of anorexia*
}

\author{
Mariana Benatto Pereira da Silva \\ Mario Eduardo Costa Pereira \\ Eloísa Helena Valler Celeri
}

\begin{abstract}
The present work deals with the issue of the analyst's desire in the psychoanalytical treatment of anorexia. It analyzes important elements to establish transference in these cases, as the pursuit of death and the choice of refusing food as a way of controlling the demands of the Other. It then discusses the "analist's desire" function in this clinic. Rejecting the definition of a treatment model and the structural categorization of anorexia, we can find in the cases of the girl of Angouleme (Charcot) and Sidonie (M. Mannoni) present possible subjective ways to get out of this psychopathological impasse, by means of this function.
\end{abstract}

Key words: Analyst's desire, anorexia and psychoanalytical clinic

* Paper taken from the Master's thesis entitled La clinique de l'anorexie et la position de l'analyste: une clinique du désir? (Clinic of the anorexia and the position of the analyst: a clinic of desire?) defended in 2007, at the Université Paris 7. 


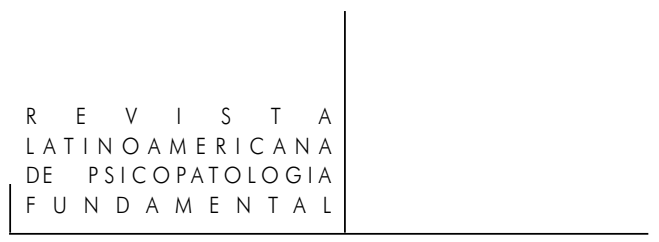

If our existence is so futile, so insignificant... let us die! I only feel life in essence when I feel I'm dying, not with that utopian happiness that goes down my throat in the form of food! (...) If one day I lie weighing 40 kilos...

30 kilos, I will die happy because I will have achieved what I wanted to.

(Erbert, 2005, p. 58)

I want to die to know who I am.

(Mannoni, 1970, p. 152)

To introduce the main point of this paper, i.e. the issue of the analyst's desire in the analytical work with anorexic patients, we will begin by analyzing the above quotes to present the context and situation facing analysts.

Both come from anorexic female adolescents: the first one was written in a pro-anorexia blog and the second one was uttered by one of Maud Mannoni's patients. They manifest a deep and shocking dimension of the demand for death found in these patients' speech.

Nevertheless, an analysis of such cases shows that this meaningful cry for death is always covered up by indifference about what is felt and experienced. This stands out, for instance, from a French adolescent's words who, after being through anorexia, wrote a book telling her story: "I want to heal alone, if I am sick. As a matter of fact, I am NOT sick, I'm on a diet, that's all. I control myself very well. I do not need to go to a doctor who won't tell anything I don't know!" (Justine, 2007, p. 23).

One of the first physicians to describe anorexia, 130 years ago, Lasègue already alerted to this peculiar aspect present in these patients' speech. He explored the doctor-patient 
relationship by comparing regular clinical patients, who look for help to alleviate their sufferings, with patients presenting what he called anorexie hystérique (hysterical anorexia): "Nothing of this sort, in the latter. To the contrary, we see an inexpugnable optimism against which all supplications and threats break. 'I don't suffer, so I'm well', such is the monotonous formula that substitutes that of the other cases: 'I can't eat because I suffer'" (Lasègue, 1971, p. 142). This can still be described exactly in the same way, nowadays. In another excerpt, this author also highlights that "excessive insistence" from a doctor or the family "leads to excessive resistance" from the patient (p. 144).

These clinical observations show precisely what we find when we work with such patients, i.e., an astonishing indifference about their morbid, usually severe state, which resists or even increases proportionally to the insistence on the fact that they need to eat. We often observe a paradoxical joyful attitude to the result reached in terms of body weight and physical appearance, considered exaggeratedly skinny by the others.

Together with the fact that they do not demand a specific treatment, this pursuit of death raises questions: what can be said on the management specificities of an analytical treatment in such situations? What should we think of the position of the analyst when faced with patients who apparently do not demand anything although they blindly follow a path toward death? From what place can the analyst take effective action in order to establish the analytical situation and direct the treatment in such cases?

\section{Clinic of anorexia?}

A preliminary question to be dealt with in such an investigation proposal can be: why should we speak of clinic of anorexia, if it is a syndrome, or even a symptom, as so many others? How should we understand anorexia, beyond a fixed structural reference?

Many different authors have tried to answer this vast question. Anorexia has already been considered, among others, a form of hysteria by Lasègue (1873) and Charcot (1890); it was compared to melancholy by Freud (1895); it was described as a form of schizophrenia by H. Bruch (1977) and situated as an "anorexic process" by Brusset (1977).

All these divergences show us the complex dimension involved in this pathology. But the question we should ask is: is it appropriate to transform anorexia into a specific clinical category? 
Our response is simple: from the psychoanalytical point of view, the term "anorexia" only describes a given clinical constellation, organized on the base of constant eating symptoms. It does not necessarily refer to an autonomous psychopathological structure, that is, one cannot claim to describe a unique treatment pattern for all these cases. It is believed that the anorexia symptom, which some authors describe as a syndrome, can exist within different contexts, either in psychosis or neurosis and perversion, depending on the case singularity. When analyzing anorexia, in 1940, Waller (1940) said: "The predominance of a specific phantasm does not exclude other conflicts and corresponding defenses. It may be one of the mechanisms that play a role in multiple psychiatric syndromes, from neurosis to psychosis" (p. 16).

Since such diversity certainly implies different managements according to each patient, it is impossible to conceive of a unique treatment model. Unlike psychiatric nosography, the psychopathological psychoanalytic perspective always takes the singularity of the analyst-analysand relationship into account, independently of the subject's pathology.

Why, then, did we choose to discuss the analyst's desire in the clinic of anorexia? In fact, despite these considerations on each analysis singularity, nobody would deny that these patients present a set of common features that arise from an unconscious psychic conflict deposited in the body, which thus becomes the center of attentions of the patients themselves and of their close circle.

But how can we understand this psychic conflict more clearly? What unconscious logic underpins this impossibility of eating?

According to Lacan (1997), "mental anorexia is not a not eating, but a eating nothing. I insist: this means eating nothing. Nothing is precisely something that exists on the symbolic plan" (p. 190). ${ }^{1}$ Therefore, in Lacan's analysis, nothing is promoted to the status of object, which, in this case, is decisive for the destiny of subjectivation.

In that same text, Lacan describes how, through this election of the object nothing (rien), children invert the relation of dependence to their mother. By refusing food, they get the power to resist to the intrusive demands of the Other and transform their mother into someone who depends on them, and no longer the contrary:

Here, they invert their dependence relationship and, by this means, take control of the avid omnipotence of making them live, them who depend on their

1. The original says: 'L'anorexie mentale n'est pas un ne pas manger, mais un rien manger, $\mathrm{j}$ 'insiste - cela veut dire manger rien. Rien c'est justement quelque chose qui existe sur le plan symbolique".

Rev. Latinoam. Psicopat. Fund., São Paulo, v. 13, n. 2, p. 207-223, junho 2010 


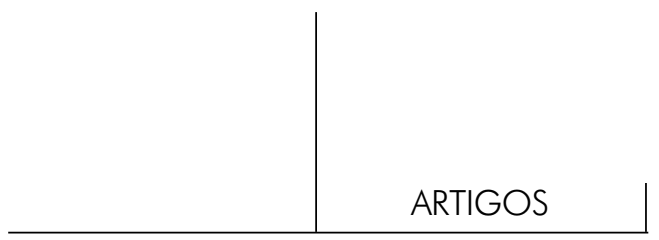

mother. From then on, it is her who depends on their desire, her who is at their mercy, at the mercy of the manifestations of their whims, at the mercy of their omnipotence. (p. 187)

This control, this power also conditions the relationship of anorexic patients to their body. The mastery of their most basic need, hunger, seems to guarantee a manner to relate to the Other. This refusal to eat can therefore be understood as a way to resist to the demands of the Other, which they feel forced to dominate. Consequently, it actually becomes the only way these patients have to affirm themselves as desiring subjects, like Mannoni (1970) shows us in her description of a case of anorexia: "It is by the way of bereavement (of a narcissist relationship to a body she abandons) that what she has lost, there, seeks to restore itself and spring up in a desiring state, that is, in the state of a subject able to fight to live" (p. 158).

This functioning through refusal, this dynamic of their relationship to the Other, which is common in these patients, certainly has consequences on the analytical treatment and, especially, on the establishment of transference, which may later allow to reach a structural diagnosis. This common feature allows us to think of a clinic of anorexia, although we carefully keep the above objections in mind.

\section{The analyst's place and treatment direction}

\section{a) The girl of Angouleme - Charcot}

To illustrate our reflection on the analyst and the treatment direction in the clinic of these patients, we will begin with a case of anorexia cared for by Charcot, in 1890. This author speaks of the importance of isolation in the cases of hysteria. Obviously, this is a medical context, but, as we will see, it allows us to identify some central elements of the analytical intervention in such situations.

In the case of this 14-years-old girl, from the city of Angouleme, France, Charcot insisted on isolation, telling her parents that, since she was in a fairly precarious state, her only chance to survive was for them to go away or at least pretend to. After having tried everything they could to cure their daughter, they eventually accepted his recommendations, though very reluctantly. Surprisingly, the girl gradually began to eat again. After two months of treatment, when she had practically recovered, she admitted:

As long as dad and mum did not leave me, in other terms, while you did not triumph - for I was aware you wanted to have me locked in - I believed my 


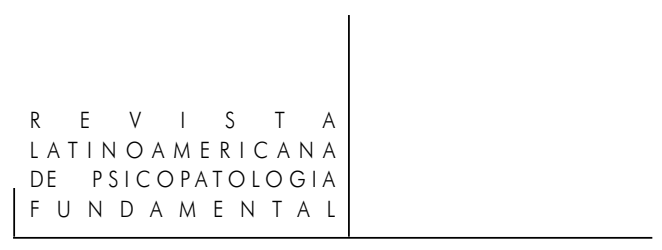

disease was not serious, and since I hated eating, I did not eat. When I saw you were ruling, I got scared and, despite my repugnance, I tried to eat and it came back gradually. (Charcot, 1890, p. 246)

Our point in quoting this excerpt is not to discuss whether or not isolation is necessary in such treatments, but to analyze why Charcot's firm intervention led to a change in the patient's subjective position.

What happened in this case? Why did this "belle indifference" ${ }^{2}$ turn into responsibility-taking toward her own body and state?

If we analyze why Charcot recommended isolation, we see that he gave a different answer to the manipulation the patient exerted on her parents. By isolating her, he began to intervene on the power of this refusal to eat, in order to, if not revert, at least suspend this dependence relationship.

More radically, the "triumph" of a doctor's authority on what used to be uncontrollable and annihilating invasions of the parental Other guaranteed her the possibility of a lack and of a separation that allowed her to situate her own desire.

What does this teach us about the current psychoanalytical clinic of anorexia? How can Charcot's place, more than 100 years ago, help us understand the transformation of a treatment refusal into a different position with regard to the symptom?

b) Demands of analysis and analyst's desire

It remains the first aim of the treatment to attach him [the patient] to it and to the person of the doctor. To ensure this, nothing need be done but to give him time.

(Freud, 1970, p. 99)

To advance our research, we propose the following question: What do anorexics really demand with this "non-demand" actively expressed in their refusal?

As we saw, in the anorexic-mother relationship, opposition constitutes a demand. That is, their refusal is a way to address the demands of the Other and to position themselves in front of them. They thus interpellate the Other so as to attack frontally its expectancies of oral satisfaction, which turn the subject into an object. Does the same hold good when the analyst is concerned? Can we think

2. "Beautiful indifference": expression used to refer to some patients' lack of concern.

Rev. Latinoam. Psicopat. Fund., São Paulo, v. 13, n. 2, p. 207-223, junho 2010 


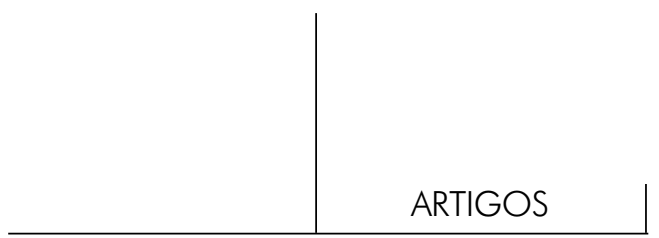

of this apparent "lack" of demands as actually being a way to demand through refusal?

Such a perspective unveils a refusal that would actually reflect a desire that cannot be recognized as such. That is, we are faced with a paradoxical logic in which refusing would actually serve to denounce the violence of the Other's expectancies placed on the subject and to provoke lack and frustration in the Other.

Therefore, should the analysts establish their first link to their patient through this logic that? Actually, the stories anorexics patients told us during this research and the cases reported in the literature show that this "lowering of guard", which allows to establish an analytical link, does not usually happen before various treatment attempts. This is so because the patients feel this therapeutic relationship as very dangerous. In fact, what they hope for and need most is at the same time what threatens them most, i.e., that the Other recognizes their condition of desiring subject.

In the above quote, Freud suggests that the action of time is an important factor to attach the patients to their therapist. Although the cases mentioned here clearly show that, we may wonder: how do analysts play a part in this dialectics? What can they offer with their clinical work, besides a waiting for the action of time? And what does the action of time do in these subjects, when in transference?

According to Lacan (1997), "What the analyst has to give, unlike the partner in the act of love, is something that even the most beautiful bride in the world cannot outmatch: what he has. And what he has is nothing other than his desire, like that of the analysand, with the difference that it is an experienced desire" (p. 360).

But what is this experienced desire of the analyst? When he discusses the issue of an answer to the demands of happiness, Lacan responds by asserting what the analyst's desire cannot be: "He cannot desire the impossible" (1997, p. 360).

Lacan thus shows us that, in this relationship, what the analyst has to offer is his desire, which is an experienced desire and, thus being, that the analyst cannot desire the unreachable: lack is thus correlative to the possibility of desire, which the analysts should be able to support in themselves.

To complete the issue of the analyst's desire, we will add that:

It is a concept - a signifier - where a function is thought - desire as a function. Freud wrote that psychoanalysts operate with their unconscious. Lacan advocates that he analyzes with his desire. (...) It (the unconscious "of" the analyst) only intervenes in the cure as the analyst's possibilities and impossibilities to listen, to be evoked and sometimes reorganized by the 
analysand's words, and to speak. This is the real, concrete manifestation of the unconscious. Its silence is only valid as possible words, as desire of that silence: the rule, the adjustment of silence and words involves the unconscious. (Guyomard, 1992, p. 19)

This shows us what this signifier "analyst's desire" is, which permeates any analytical treatment, unveiling the possibilities and impossibilities of the analystanalysand relationship. This possibility of listening, interpellating and transforming, which exists in this relationship, is the tool analysts have at their disposal to intervene in the analytical process, even with anorexic patients.

Therefore, if this function guides all the work of the analyst's unconscious, with its possibilities and limitations, what can we say of it within a clinic in which the patient's desire can only appear imaginarily in the disappearance of the body?

Since the analyst's desire serves to transform the analysis into the place where subjects can be faced by their desire, in the clinic of anorexia, the analysts' function will be to offer their patients a new possibility to sustain their unconscious desire, which goes beyond body negation: the lack that subjects need so much to establish their own desire cannot be threatened by the intrusive presence of the Other, with its demands and expectancies utterly addressed to them, which reduce them to the condition of object of its fantasy.

To clarify the place held by the analyst, we will quote Guyomard (1992) when he refers to this confrontation dynamic: "The dialectics and the otherness of desire - desire as a desire of desire - imply that the subjects only question their desires or how they are constituted and strengthened (their fantasies) in reference to this otherness" (p. 19). We may thus understand that subjects are led to address to their own desire through the dialectics of the desire of desire, owing to the intervention of the "analyst's desire" function. When it comes to anorexic subjects, this condition entails the greatest threats: - what object will I be in the fantasy of this Other? - What are the limits of its desiring project, which includes me as its object?

Mannoni (1970) also approaches this dialectics: "It is from the place of the Other that the analyzed subjects articulate their: - What do you want of me? Which transforms into: - what do I want? These questions of the unconscious are precisely those recovered by the very first signifiers of desire" (p. 138).

In anorexic patients, these first signifiers of desire are apparently still fairly connected to the body and cannot emerge otherwise than through this mortiferous dynamic against themselves. According to Mannoni, this occurs because these subjects are still attached to a maternal imago, felt as devouring. This is why their only way "to manage to arise as desiring subjects, out of the mother's desire" (p. 154) is to refuse to eat. 


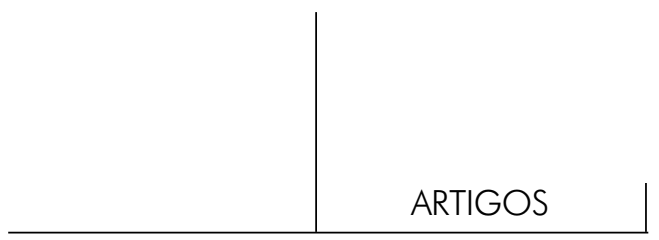

In this context, at least in the beginning, these patients see analysis as a path paved with terrible threats against their own desire, which emerge in their relationship to the Other, because, as Freud showed, during analysis, unconscious reality actualizes itself in repetition. The analyst thus has to occupy a different place and be an ally of the singular desire (Assoun, 2006, p. 77) of that unique subject, a place apart from the injunctions of the Other, which nobody else could hold, not even the family or a medical team.

Coming back to Charcot and his patient, may we think that the direction he chose is an example of answer given from a different place? Is Charcot's attitude, which, in the beginning, his patient's close circle did not understand, an attempt to interrupt this mortiferous dynamic of repetition that perpetuated itself in the manipulation relationship that existed in her family? Or else, more radically, does not Charcot perform a symbolic cut in the presence of the family Other, thus far experienced as omnipotent and limitless?

\section{c) Sidonie's treatment - M. Mannoni}

To better illustrate this different position of the analyst made possible by his desire function, we will resort to a brief analysis of Sidonie's case presented in M. Mannoni's (1970) book Le psychiatre, son "fou " et la psychanalyse (The psychiatrist, his "madman" and psychoanalysis, p. 139-162).

Seventeen-years-old Sidonie was a female adolescent who suffered from severe anorexia since she was 15 . She had already been hospitalized five times, all of them in isolation. Fed by force, she always left the hospital healthy, although revolted and disobedient. Nevertheless, as soon as she came back home, her behavior reappeared: hunger strike, excessive ingestion of vinegar, aspirin or lemon juice, until she was hospitalized once again. This cycle repeated itself and the patient's parents had already attempted everything to interrupt it. However, Sidonie had discouraged all the medical teams, which already considered her as a chronic patient.

Her parents then took her to a psychoanalyst, thinking: "Since nothing worked, (...) let's try a psychoanalyst!" (p.139).

Although they were concerned about her state, they had no more forces and needed holidays. Fearing to leave his daughter on her own, the father asked: "Will you take responsibility if Sidonie faints in the street?" Mannoni answered:

I do not take any responsibility, except that of conducting the analysis. Dr. Y said that, with what she eats, Sidonie could endure at least two months. He will decide whether or not we hospitalize her in two month time. For the time being, Sidonie has to tell us if she will take care of her body, if she takes the responsibility of bringing me her body at the established times and days. (p. 140) 


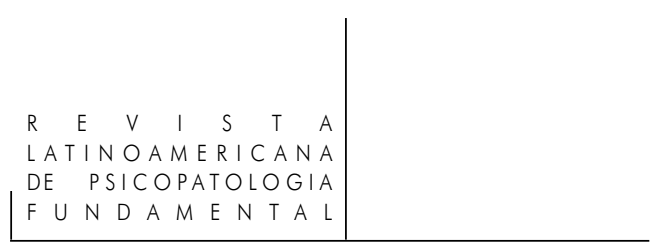

Here, Mannoni clearly delimits her role as an analyst by rejecting a responsibility that, as many authors showed us, ${ }^{3}$ cannot be part of the analyst's function, especially in such cases: that of desiring in the place of the very subject, even if this desire refers to safeguarding vital functions. Rejecting any responsibility for the patient's life, she thus preserves the analytical link and guarantees the vacuum in which, possibly, the patient's desire will be able to settle.

The treatment continued and, anxious and guilty because of the freedom she had during her parents' holidays, the patient demanded to be hospitalized. The analyst granted her request, but insisted:

It is your body that must take care of itself. You want us to tear into you by any means. Then you say: it is the bad one, the dreadful one. The others are always wrong. You never have anything to do with what happens to you. You are here as in a movie: Look, ladies and gentlemen, what they are making of me. (p. 144)

This intervention shows above all that Mannoni tries to have her patient take responsibility for the way she uses her disease as a manner to address to the Other. She highlights the participation of the subject as the agent, in her own psychopathology: her symptom is a concealed way of interpellating the Other by challenging it to play, in the reality, the terrible role it plays in her fantasy.

The analysis continued while Sidonie was hospitalized in total freedom. With no obligations or forced nutrition, the patient experienced a moment of euphoria while her body got increasingly weak. One day, Mannoni found her lying in the Sun, almost unconscious and said: "I accept you either dead or alive" (p. 148). Scared, the patient got up and said that she did not want to die.

This intervention demonstrates the extent of the analyst's respect for her patient's desire. Unlike those who surrounded her, Mannoni showed she was not focused on the morbid aspect of the disease and, consequently, that she could accept that wish of death for her body, which regarded her patient's desire.

A few days later, her patient consolidated her death wish by uttering the second epigraph of this paper: "I want to die to know who I am" (1970, p. 152).

Then, analyzing the effects of her interventions, Mannoni asserts:

3. On the need for a multifocal team so that the analyst can be free to act as an analyst only, see: Jeammet, P., La thérapie bifocale, Adolescence, v. 10, n. 2, 1992; Jeammet, P., Anorexie et Boulimie, les paradoxes de l'adolescence, Paris: Hachette Littératures, 2005; Birot, E., Chabert, C., et Jeammet, P. Soigner l'anorexie et la boulimie, Paris: PUF, 2007. 


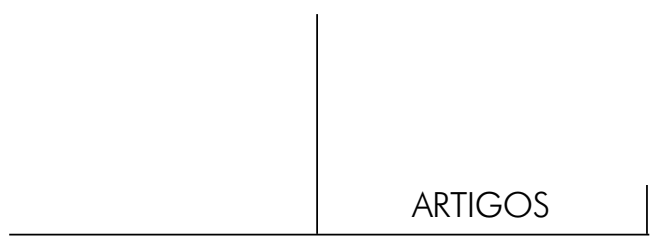

By ratifying, at the beginning of her stay, her wish to destroy her body ("I accept you either dead or alive"), I privileged the maintenance of desire, desire which was forbidden by an archaic maternal superego. But I left intact the fascination that a certain game with death exerted on her. She had to feel its effect on the others to measure their desire of seeing her alive. (p. 153)

We thus understand that, through the repetition of her "game", intended to measure the eagerness of the others to see her alive, since she refused to eat, she fed her own desire. This dynamic was also present in the analysis, but it gave Sidonie a different answer, which allowed the emergence of a new way to position herself in the world and to get of this maternal archaic forbiddance and begin to found her place as a desiring subject.

\section{d) Analyst's desire, castration and Sidonie's case}

Reflecting on Mannoni's answer to her patient, we may ask: How does this different position of the analyst establishes itself through her desire? What has favored the emergence of this function in the analysis?

Subjects only find limits and references to their desire by leaning on the desire of others who manage to get to this place. The analyst's desire is the concept of this set of questions; for analysts, the relationship to the analyst's desire involves their castration more than their own desire. For them, remaining psychoanalysts has less to do with withstanding their desire than with withstanding their castration. (Guyomard, 1992, p. 20)

The above quotation makes us seize the difference between the analyst's personal desire and the analyst's desire as a function. We may understand that the analyst's desire is much closer to the analyst's castration than to any personal desire, since desire precisely springs from lack.

Assoun (2006) also approached this thematic when he spoke of the features Freud associated with analysts:

We can see the astonishing portrait that emerges from such "features". They go from the most pragmatic aspect to the capacity of disappearing without fading, of staying in the background without being eclipsed, in short, of signifying one's analyst's desire without imposing one's orgasm (jouissance). (p. 78)

In this regard, succumbing to their own desire would mean imposing their own orgasm (jouissance) to their patient, which would be contrary to the goal of any analysis: creating a space for the patient's desire to emerge.

Guyomard (1992) adds that: "Castration originates desires, it makes them possible and founds their possibilities on a loss. Without it, desire stays away or 


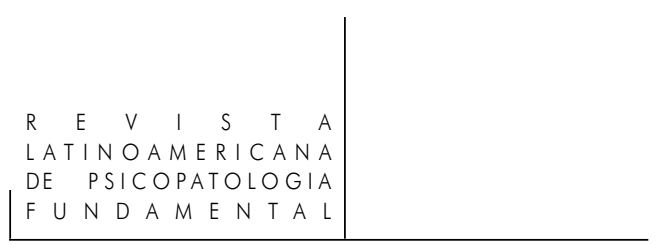

its value reverts into omnipotence (toute-puissance). (...) Castration is the limit to its omnipotence (toute-puissance)" (p. 20-21).

Coming back to Sidonie's case, it is precisely this inversion of desire into omnipotence that occurred when, during analysis, Mannoni (1970) had to abandon her analyst's role, as she acknowledges herself.

When her patient was being hospitalized, to allow for Sidonie to be admitted into a clinic where she would be given total freedom, she had to accept the entire responsibility for both her treatment and her life: "But I was also abandoning my analyst's role and revealing my desire. I had even formulated this desire clearly: I rejected the traditional psychiatric system, which, in this case, had only led to failure. Since Sidonie wished to go to the threshold of death (of the body), there she went" (p. 146).

Actually, this abandonment of her analyst's role occurred as a way to respect her patient's wish of death for her body, i.e., her desire was to impel Sidonie towards her own desire. That the analyst had gained control over the whole situation did not go unnoticed by the patient who began to treat her as an omnipotent, magic person who ruled everything and everybody: "I wanted to remain an analyst conscious of having already usurped many roles, and of having gone along with Sidonie much farther than I would have liked. And what Sidonie tried to experience was exactly something of the order of my magical omnipotence. In a sense, she believed I controlled everything: her parents, the clinic, the doctors" (p. 145). The analyst's desire had been transformed into magical, limitless omnipotence, therefore into an impossible desire, without lack.

Nevertheless, after Sidonie was admitted into the clinic, Mannoni took back her analyst's place: she left the responsibility of treating Sidonie to the clinic team and reserved for herself the work of listening and of sustaining the transference. Thus, privileging the way of castration and not that of the omnipotence of her desire, the analyst took back her path, founding a perspective of loss and lack, and, therefore, a possibility of access to the origin of desire.

This possibility also showed in Sidonie's speech: "Everybody is happy because I'm healed. They do not realize that it's not the important matter. They do not understand that what counts are my wills. It's my wills that the voices ${ }^{4}$ kill. They hunt them to extinction. What's the point of being alive if I am condemned to the death of my wills?"(1970, p. 153).

4. The patient heard voices that told her not to eat. For further information, please consult Mannoni's book Le psychiatre, son "fou" et la psychanalyse (The psychiatrist, his "madman" and psychoanalysis), 1970.

Rev. Latinoam. Psicopat. Fund., São Paulo, v. 13, n. 2, p. 207-223, junho 2010 
In the analytical relationship, Sidonie unveiled this forbiddance of "her wills", which may represent a great step ahead to find a place as a desiring subject. As Mannoni put it: "What, until then, had been refused by the subject and shielded from any symbolic articulation reappeared in the language" (1970, p. 160).

Thus, this clinical articulation shows the importance of the analyst's castration, since, although compelled to stay at her place, i.e., to keep desiring, it allowed the analytical relationship to take place and work.

\section{Conclusion}

This work allowed us to understand that the establishment of the analytical device in a cure process with anorexic patients depends on a complex combination of numberless factors, among which, the place held by the analyst's desire is a crucial element.

We analyzed how, through the analyst's desire, i.e., his possibility to keep desiring, to support a lack, the analyst can lead his patients to work on their desire.

This research helped us comprehend that, in the case of anorexic patients (and in any case, actually), an analysis goes much beyond the issues of the symptom. This centralization on the problematic of anorexia, common in the beginning of treatment, would only be a necessary step to have access to the subject, which stays in the background, hidden by the issues of the body and by the stereotype of the anorexic patient. We could thus say that the path would be an analytical process that keeps anorexia aside and gives the patients a minimum of references so that they skip to the questions on their position as subjects, often raised through the very symptom.

Nonetheless, one question subsists: would this passage from the clinic of anorexia to the subject's analysis, permeated by the function of the analyst's desire, be possible in any case? Even in the most severe ones? Would this search for the subject of the unconscious in the clinic of anorexia be different from that of other, so called "difficult" clinics?

We know that the questions here proposed are not closed and that, to the contrary, they open research perspectives that seem very pertinent if we consider the clinic that faces us in our present daily life. Working with "difficult" patients or with what may also be called the 'clinic of regression' interpellates us with questionings and problematics as the ones discussed above and therefore demands to be deepen. 


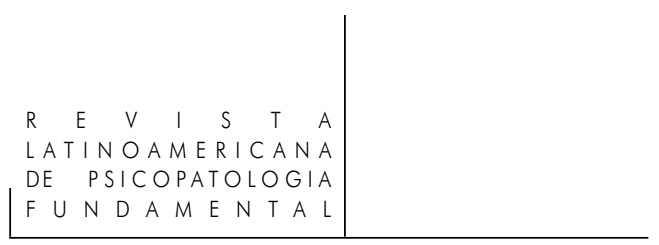

\section{References}

Assoun, P-L. Leçons psychanalytiques sur le transfert. Paris: Anthropos, 2006.

Birot, É.; Chabert, C.; JeAmmet, P. (dir.). Soigner l'anorexie et la boulimie. Paris: PUF, 2007.

BRUCH, H. Les yeux et le ventre: l'obèse, l'anorexique. Paris: Payot, 1984.

Brusset, B. L'assiette et le miroir. Toulouse: Privat, 1977.

Charcot, J-M. "De l'isolement dans le traitement de l'hystérie", dix-septième leçon sur les maladies du système nerveux. In: Euvres complètes. Paris: Le progrès médical/Lecrosnier et Babé, 1890. Tome III, p. 238-252.

ERbert, T. C. Anorexia e bulimia nervosa: blogs e casos reais. São Paulo: Marco Zero, 2005.

FReUd, S. (1895). Rascunho G. In: Edição Eletrônica Brasileira das Obras Psicológicas Completas de Sigmund Freud. Rio de Janeiro: Imago. p. 96-104.

. Le début du traitement. In: La technique psychanalytique. Paris: PUF, 1970.

220 Guyomard, P. La jouissance du tragique: Antigone, Lacan et le désir de l'analyste. Paris: Aubier, 1992.

Jeammet, P. La thérapie bifocale. Adolescence, Paris, v. 10, n. 2, p. 371-383, 1992. . Anorexie et boulimie, les paradoxes de l'adolescence. Paris: Hachette

Littératures, 2005.

Justine. Ce matin j'ai décide d'arrêter de manger. Mesnil-sur-l'Estrée: Oh! Editions, 2007.

Lacan, J. Le séminaire. Livre IV. La relation d'objet. Paris: Seuil, 1994. 1997.

. O seminário. Livro 7. A ética da psicanálise. Rio de Janeiro: Jorge Zahar,

. Interversion sur le transfert. In: Écrits I. Paris: Seuil, 1999. p. 212-223.

LasÈgue, C. De l'anorexie hystérique. In: Ecrits psychiatriques. Toulouse: Privat, 1971. p. 142-144.

Mannoni, M. Le psychiatre, son "fou” et la psychanalyse. Paris: Seuil, 1970.

Waller, J.V.; Kaufman, R.M.; Deutsch, F. Anorexia nervosa: a psychosomatic entity. Psychosom. Med., n. 2, p. 3-16, 1940. 


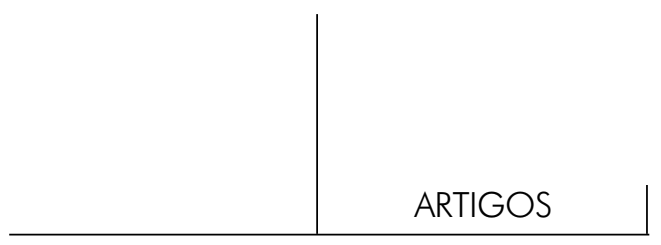

Resumos

(O desejo do analista na clínica da anorexia)

O presente trabalho trata da questão do desejo do analista no tratamento psicanalítico da anorexia. Com esse objetivo, portanto, analisamos elementos importantes para o estabelecimento da situação analítica com esses pacientes - como a busca pela morte e a eleição da recusa a se alimentar como uma forma de controle da demanda do Outro - para então discutir a função "desejo-do-analista” nessa clínica. Recusando uma categorização estrutural da anorexia e também a definição de um modelo de tratamento, encontramos nos casos da jovem de Agoulême, de Charcot, e de Sidonie, paciente de M. Mannoni, saídas subjetivas possíveis para esse impasse psicopatológico, atingidas através dessa função.

Palavras-chave: Desejo do analista, anorexia e clínica psicanalítica

(Le désir de l'analyste dans la clinique de l'anorexie)

Le présent travail porte sur la question du désir de l'analyste dans la clinique de l'anorexie. À cette fin, nous analyserons quelques éléments importants qui contribuent à l'établissement de la situation analytique des patients - par exemple, la recherche de la mort et le refus de se nourrir comme façon de contrôler la demande de l'Autre pour ainsi discuter la fonction "désir de l'analyste" dans le contexte de cette clinique. Nous refusons non seulement la catégorisation structurelle de l'anorexie, mais encore la définition d'un modèle de traitement et trouvons dans les cas de la jeune fille d'Angoulême (Charcot) et de Sidonie (M. Mannoni) des solutions subjectives à cette impasse psychopathologique, rendues possible grâce à cette fonction.

Mots clés: Désir de l'analyste, anorexie et clinique psychanalytique

(El deseo del psicoanalista en el tratamiento psicoanalítico de la anorexia)

El presente trabajo trata de la cuestión del deseo del analista en el tratamiento psicoanalítico de la anorexia. Con ese objetivo, analizamos elementos importantes para el establecimiento de la situación psicoanalítica con estos pacientes - tales como la búsqueda por la muerte y la elección de la recusa a alimentarse como una forma de control de la demanda del Otro - para así poder discutir la función del deseo del analista en esa clínica. Recusando una categorización estructural de la anorexia y también la definición de un modelo de tratamiento, encontramos en los casos de la joven de Agoulême de Charcot y de Sidonie, paciente de M. Mannoni, salidas subjetivas posibles para ese embarazo psicopatológico, alcanzados a través de la función del deseo del analista.

Palabras claves: Deseo del analista, anorexia y clínica psicoanalítica 


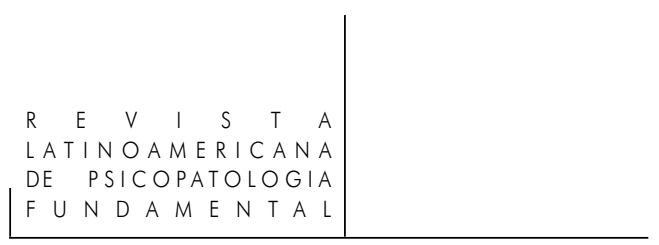

Citação/Citation: Silva, M.B.P. DA; Pereira, M.E.C.; Celeri, E.H.R.V. The analyst's desire in the clinic of anorexia. Revista Latinoamericana de Psicopatologia Fundamental, São Paulo, v. 13, n. 2, p. 207-223, jun. 2010.

Editor do artigo/Editor: Prof. Dr. Manoel Tosta Berlinck

Recebido/Received: 17.8.2009 / 8.17.2009 Aceito/Accepted: 4.11.2009 / 11.4.2009

Copyright: ( $) 2009$ Associação Universitária de Pesquisa em Psicopatologia Fundamental/ University Association for Research in Fundamental Psychopathology. Este é um artigo de livre acesso, que permite uso irrestrito, distribuição e reprodução em qualquer meio, desde que $\mathrm{o}$ autor e a fonte sejam citados/This is an open-access article, which permits unrestricted use, distribution, and reproduction in any medium, provided the original author and source are credited.

Financiamento/Funding: Os autores declaram não terem sido financiados ou apoiados/The authors have no support or funding to report.

Conflito de interesses/Conflict of interest: Os autores declaram que não há conflito de interesses/The authors declare that has no conflict of interest.

\section{Mariana Benatto Pereira da Silva}

Psychologist; Graduated at the Universidade Federal do Paraná - UFPR (Federal University of Paraná - Curitiba, PR, Brazil); Master in psychology from the Université Paris 7 - Denis Diderot (Paris, France) with a specialization in psychoanalytical anthropology and clinic of the body.

Rua Deputado Carneiro de Campos, 187 - Hugo Langue

80040-320 Curitiba, PR, Brasil

Fone: (41) 3252-5868/3335-3650

e-mail: maribenatto@yahoo.com.br

\section{Mario Eduardo Costa Pereira}

Psychiatrist; Psychoanalyst; Professor at the department of Medical Psychology and Psychiatry of the Universidade Estadual de Campinas - Unicamp (State University of Campinas, Campinas, SP, Brazil); Habilitation pour Diriger des Recherches (HDR) from the Université de Provence; Doctor in Fundamental Psychopathology and Psychoanalysis from the Université Paris 7 (Paris, France); Director of the Laboratório de Psicopatologia Fundamental (Laboratory of Fundamental Psychopathology) of Unicamp; Professor livre-docente from the Department of Psychoanalysis; Member of the Institute Sedes Sapientiae (São Paulo, SP, Brazil); Member of the Associação Universitária de Pesquisa em Psicopatologia Fundamental (University Association of Research in Fundamental Psychopathology - São Paulo, SP, Brazil); Full Professor of Clinical Psychopathology and member of the Laboratoire of Psychopathologie Clinique et Psychanalyse (Laboratory of Clinical Psychopathology and Psychoanalysis) of the 


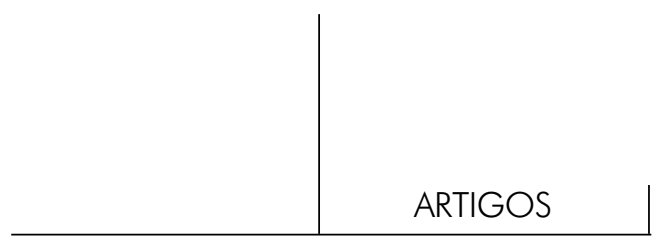

Université de Provence/Aix-Marseille (Marseille, France).

Université de Provence

Centre Saint-Charles

Case 37

3, place Victor Hugo

13331 Marseille cedex 3 France

e-mail: marioecpereira@uol.com.br

\section{Eloisa Helena Rubello Valler Celeri}

Psychiatrist; Psychoanalyst and professor at the department of Medical Psychology and Psychiatry of the Universidade Estadual de Campinas - Unicamp (State University of Campinas, Campinas, SP, Brazil); Director of the Laboratório de Psicopatologia Fundamental (Laboratory of Fundamental Psychopathology) of Unicamp.

Rua Santo Antonio, 60/61 - Cambuí

13024-440 Campinas, SP, Brasil

Fone: (19) 3521-8819

e-mail: evaller@fcm.unicamp.br 